\begin{tabular}{|c|c|c|}
\hline & $\begin{array}{c}\text { Jurnal Bidan Cerdas } \\
\text { e-ISSN: 2654-9352 dan p-ISSN: 2715-9965 } \\
\text { Volume 3 Nomor 4, 2021, Halaman 183-190 } \\
\text { DOI: } 10.33860 / \text { jbc.v3i4.509 } \\
\text { Website: http://jurnal.poltekkespalu.ac.id/index.php/JBC/ } \\
\text { Penerbit: Poltekkes Kemenkes Palu }\end{array}$ & 2 \\
\hline
\end{tabular}

\title{
Pemberian Sari Kacang Hijau dan Tablet Tambah Darah Terhadap Peningkatan Kadar Hemoglobin pada Remaja Putri
}

\author{
Hastuti Usman $₫ \mathbb{D}^{1}$, Niluh Nita Sifia ${ }^{2}$, Artika Dewie $\mathbb{D}^{3}$, Evi Mariani ${ }^{4}$ \\ ${ }^{1}$ Prodi Sarjana Terapan Kebidanan, Poltekkes Kemenkes Palu, Indonesia \\ ${ }^{2}$ Prodi D-III Kebidanan Palu, Poltekkes Kemenkes Palu, Indonesia \\ ${ }^{4}$ Puskesmas Kinovaro, Indonesia \\ 凹Email: firel.family@gmail.com
}

\section{ARTICLE INFO Article History: \\ Received: 2021-09-06 \\ Accepted: 2021-11-30 \\ Published: 2021-11-30}

\section{Kata Kunci:}

Sari kacang hijau: Tablet tambah darah; Hemoglobin; Remaja

\section{Keywords:}

Green bean juice; Blood boost tablets; Hemoglobin; adolescents.

\begin{abstract}
ABSTRAK
Pendahuluan: Kejadian Anemia pada perempuan lebih tinggi yaitu 27,2\% dibandingkan laki-laki 20,3\%, terbanyak pada kelompok umur 15-24 tahun. Penurunan kadar hemoglobin disebabkan karena rendahnya asupan zat besi dan zat gizi lainnya serta adanya proses menstruasi. Cakupan pemberian tablet tambah darah Kabupaten Sigi pada tahun 2019 sebesar $81,25 \%$. Tujuan penelitian ini untuk mengetahui pengaruh pemberian sari kacang hijau dan tablet tambah darah terhadap peningkatan kadar hemoglobin pada remaja putri. Metode Penelitian Quasi eksperimen dengan metode pretestpostest control group design. Populasi adalah remaja putri usia 12 sampai 16 tahun dengan jumlah 32 responden. Penelitian dilakukan di wilayah kerja Puskesmas Kinovaro. Hasil Hasil kadar $\mathrm{Hb}$ pada remaja putri setelah diberikan intervensi sari kacang hijau dan tablet tambah yaitu $2 \mathrm{gr} / \mathrm{dl}$ dengan nilai $p=0,022$ yang berarti terdapat perbedaan yang bermakna sebelum dan sesudah pemberian sari kacang hijau dan tablet tambah darah terhadap peningkatan kadar hemoglobin remaja putri. Kesimpulan: Pemberian sari kacang hijau dan tablet tambah darah berpengaruh secara signifikan terhadap peningkatan kadar hemoglobin pada remaja putri. Saran yaitu pemberian kacang hijau dan tablet tambah darah 1 minggu sekali sangat bermaat bagi remaja putri dalam mengatasi anemia.
\end{abstract}

\section{ABSTRACT}

Introduction: The incidence of anemia in women is $27.2 \%$ higher than men, $20.3 \%$, mostly in the age group 15-24 years. The decrease in hemoglobin levels is caused by low intake of iron and other nutrients as well as the menstrual process. The coverage of giving blood tablets in Sigi Regency in 2019 was $81.25 \%$. The purpose of this study was to determine the effect of giving green bean juice and blood-added tablets to increase hemoglobin levels in adolescent girls. Methods: Quasi-experimental research method with pretest-posttest control group design method. The population is young women aged 12 to 16 years with a total of 32 respondents. The research was conducted in the working area of the Kinovaro Health Center. Results: The results of $\mathrm{Hb}$ levels in adolescent girls after being given the intervention of mung bean juice and added tablets are $2 \mathrm{~g} / \mathrm{dl}$ with a p-value of 0.022, which means that there is a significant difference before and after giving green bean juice and blood-added tablets to the increase in hemoglobin levels of adolescent girls. Conclusion: Giving mung bean juice and blood-added tablets had a significant effect on increasing hemoglobin levels in adolescent girls. Suggestions are giving green beans and blood-added tablets once a week is very beneficial for young women in overcoming anemia. 


\section{PENDAHULUAN}

Word Health Organisasion (WHO) mendefenisikan 'Remaja' adalah individu dalam kelompok usia 10-24 tahun. Usia rentan pada remaja yaitu kelompok umur 10-24 tahun. Salah satu masalah yang dihadapi remaja Indonesia adalah masalah gizi mikronutrien, yakni sekitar $12 \%$ remaja laki-laki dan $23 \%$ remaja perempuan mengalami anemia Anemia dikalangan remaja perempuan lebih tinggi dibanding remaja laki-laki karena remaja putri mengalami masa menstruasi (Kementerian Kesehatan R.I., 2018c)

Kebutuhan gizi sangat diperlukan oleh remaja dalam proses pertumbuhan, anjuran untuk minum tablet tablet tambah darah (TTD) 1 tablet setiap minggu sebagai upaya pencegahan anemia, karena remaja putri mengalami menstruasi setiap bulannya, yang menjadi sebab terbesar anemia remaja putri. Petugas kesehatan dapat berperan untuk mengurangi kejadian anemia remaja dengan memberikan penyuluhan berupa asupan nutrisi yang tepat bagi remaja. Peningkatan pengetahuan remaja terhadap makanan yang mengandung zat besi tinggi terutama jus kacang hijau dapat dikonsumsi untuk meningkatkan kadar Hb (Yuviska \& Armiyanti, 2019).

Menurut penelitian Retnodini,dkk bahwa setelah mengkonsumsi tablet tambah darah (TTD) dan kacang hijau kadar hemoglobin ibu hamil dapat meningkat dibandingkan dengan dengan ibu hamil yang hanya mengkonsumsi tablet tambah darah (Retnorini, Widatiningsih, \& Masini, 2017). Berdasarkan analisis jurnal Rimawati, dkk yang telah dilakukan didapatkan bahwa dalam meningkatkan Hemoglobin dalam darah tidak hanya diatasi dengan pemberian suplemen Fe (tablet tambah darah) tetapi juga diperlukan pemberian suplemen makanan (Rimawati, Kusumawati, Gamelia, Sumarah, \& Nugraheni, 2018). Penelitian lain yang dilakukan di Remaja SMA mengatakan bahwa konsumsi kacang hijau dan madu dapat meningkatkan kadar hemoglobin dalam darah (Kurniyati et al., 2021).

Data Riskesdas 2018 proporsi anemia pada perempuan 27,2 \% lebih tinggi dibandingkan pada laki-laki yaitu 20,3\%. Proporsi anemia pada kelompok umur 15-24 tahun sebesar 32\% (Kementerian Kesehatan R.I., 2018a). Prevalesi Anemia yang terjadi di Kabupaten Sigi belum tergambarkan secara jelas akan tetapi program pusat yang telah dilaksanakan untuk mengatasi terjadinya anemia adalah pemberian tablet tambah darah (TTD). Proporsi remaja putri yang mendapatkan tablet tambah darah (TTD) di sekolah untuk yang mendapatkan tablet tambah darah sebanyak $76,2 \%$ atau 80,9 (Kementerian Kesehatan R.I., 2018c). Data Dinas Kesehatan Provinsi Sulawesi Tengah pada tahun 2018, kejadian anemia pada kelompok usia 10-14 tahun sebanyak 431 orang $(0,16 \%)$ dari 264.915 jiwa, kelompok umur 16-18 tahun sebayak 454 orang $(0,17 \%)$ dari 263.416 jiwa (Kementerian Kesehatan R.I., 2018b). Kota Palu jumlah anemia pada kelompok 10-14 tahun sebanyak 16 orang dan 16-18 tahun sejumlah 22 orang. Pemberian tablet tambah darah (TTD) pada remaja putri yaitu $76,66 \%$, pada tahun 2019 mengalami peningkatan yang signifikan menjadi 84,7\% pemberian TTD pada remaja putri.

Data menurut Dinas Kesehatan Kabupaten Sigi pada tahun 2018 jumlah pemberian TTD yaitu 71,9\%, tahun 2019 terjadi peningkatan dengan jumlah 81,25\% pemberian TTD pada remaja putri, presentasi remaja putri yang mendapat TTD dibawah 60\% terdapat di Kecamatan Kinovaro tahun 2018 berjumlah 51,8\% sedangkan pada tahun 2019 yaitu 59,21\%, dengan pemberian tablet TTD di wilayah kerja Puskesmas Kinovaro berjumlah 90 Remaja Putri dari jumlah sasaran 152 remaja putri. Penelitian ini bertujuan untuk mengetahui pengaruh pemberian sari kacang hijau dan tablet tambah darah terhadap peningkatan kadar hemoglobin pada remaja putri di wilayah kerja Puskesmas Kinovaro 


\section{METODE PENELITIAN}

Penelitian ini dilksanakan di desa Porame dan Desa Balane Wilayah Kerja Puskemas Kinovaro pada bulan Juli 2020 dengan menerapkan protokol covid. Metode yang digunakan dalam penelitian ini adalah quasi eksperimen (eksperimen semu) dengan desain penelitian pretest-posttest control group design. Populasi yaitu remaja putri yang berumur 12-16 tahun di dua desa di wilayah kerja Puskesmas Kinovaro berjumlah 989 orang, penentuan sampel dengan menggunakan rumus besar sampling sehingga didapatkan hasil 32 remaja putri yang dibagi menjadi dua kelompok yaitu 16 remaja putri untuk kelompok intervensi dan 16 remaja putri untuk kelompok kontrol. Teknik pegambilan sampel menggunakan purposive sampling sesuai dengan pertimbangan peneliti berdasarkan kriteria inklusi yaitu remaja putri yang berdomisili di kedua desa, dengan rentang usia 12-16 tahun dan sudah menarche, kondisi tubuh sehat dan tidak menstruasi saat penelitian, serta bersedia dilakukan observasi.

Kelompok intervensi diberikan sari kacang hijau dan tablet tambah darah, sedangkan kelompok control di berikan TTD saja. Pemberian sari kacang hijau dalam ukuran gelas $250-300 \mathrm{ml}$ untuk responden selama 7 hari pada waktu pagi dan sore serta pemberian tablet tambah darah satu kali seminggu. Pengumpulan data dilakukan dengan cara melakukan pemeriksaan hemoglobin sebelum dan sesudah intervensi pada kedua kelompok. Asupan makanan responden selama penelitian berlangsung tidak diteliti. Analisis yang digunakan dalam penelitian ini adalah analisis univariat dan bivariat, Analisa data dengan menggunakan uji paired samples $t$-test pada kelompok intervensi dan kelompok kontrol dengan tingkat kepercayaan kepercayaan 95\%. Hasil uji analisis menggunakan $t$-test dependent untuk mengetahui adanya perbedaan kadar hemoglobin sebelum dan sesudah diberikan intervensi dan akan dibandingkan dengan kelompok kontrol (tanpa intervensi), dan uji uji $t$-tes independent untuk mengetahui adanya pengaruh pemberian sari kacang hijau dan tablet tambah darah (Fe) terhadap peningkatan kadar hemoglobin remaja putri. Penelitian ini telah lulus layak etik poltekkes kemenkes Palu. Penyajian data dilakukan menggunakan tabel dan narasi.

\section{HASIL PENELITIAN}

Hasil penelitian ini dapat disajikan sebagai berikut:

Tabel 1. Distribusi Frekuensi Menurut Karakteristik Remaja Putri di wilayah Kerja Puskesmas Kinovaro.

\begin{tabular}{ccccc}
\hline \multirow{2}{*}{ Umur } & \multicolumn{2}{c}{ Intervensi } & \multicolumn{2}{c}{ Kontrol } \\
\cline { 2 - 5 } & Jumlah & Persen (\%) & Jumlah & Persen (\%) \\
\hline 12 tahun & 2 & 12,50 & 0 & 25,00 \\
13 tahun & 3 & 18,75 & 4 & 25,00 \\
14 tahun & 6 & 37,50 & 4 & 25,00 \\
15 tahun & 1 & 6,25 & 3 & 18,75 \\
16 tahun & 4 & 25,00 & 5 & 31,25 \\
\hline Total & 16 & 100,00 & 16 & 100,00 \\
\hline
\end{tabular}

Sumber: Data Primer, 2020

Berdasarkan tabel 1 menunjukan bahwa dari 32 responden yang terbagi menjadi 2 kelompok yaitu kelompok intervensi dan kelompok kontrol. Kelompok intervensi berjumlah 16 responden, dengan umur yang paling banyak yaitu 14 tahun berjumlah 6 orang $(37,5 \%)$ dan paling sedikit umur 15 tahun 1 orang $(6,25 \%)$. Kelompok kontrol dengan umur yang paling banyak yaitu 16 tahun berjumlah 5 orang $(31,25 \%)$ dan paling sedikit umur 15 tahun 3 orang $(18,75 \%)$. 
Tabel 2. Distribusi Frekuensi Kadar Hb Remaja Putri Sebelum diberikan Sari kacang hijau dan tablet tambah darah di wilayah Kerja Puskesmas Kinovaro

\begin{tabular}{ccccc}
\hline \multirow{2}{*}{ Kadar Hb (gr\%) } & \multicolumn{2}{c}{ Intervensi } & \multicolumn{2}{c}{ Kontrol } \\
& Jumlah & Persen (\%) & Jumlah & Persen (\%) \\
\hline $9,01-10,00$ & 2 & 12,50 & 1 & 6,25 \\
$10,01-11,00$ & 1 & 6,25 & 2 & 12,50 \\
$11,01-12,00$ & 0 & 0,00 & 4 & 25,0 \\
$12,01-13.00$ & 6 & 37,50 & 3 & 18,75 \\
$13,01-14,00$ & 4 & 25,00 & 3 & 18,75 \\
$14,01-15,00$ & 3 & 18,75 & 3 & 18,75 \\
Total & 16 & 100.00 & 16 & 100,00 \\
\hline
\end{tabular}

Sumber: Data primer, 2020

Pada tabel 2 terlihat kadar $\mathrm{Hb}$ remaja putri sebelum diberi intervensi sari kacang hijau dan tablet tambah darah terbanyak di angka 12,01 - 13 gr\% sejumlah 6 orang (37,5\%), sedangkan kadar $\mathrm{Hb}$ remaja putri yang belum diberikan tablet tambah darah saja terbanyak pada angka 11,01 - 12,00 gr\% sejumlah 4 orang (25\%).

Tabel 3. Distribusi Frekuensi Kadar Hb Remaja Putri Sesudah diberikan Sari kacang hijau dan tablet tambah darah di wilayah Kerja Puskesmas Kinovaro

\begin{tabular}{ccccc}
\hline \multirow{2}{*}{ Kadar Hb (gr\%) } & \multicolumn{2}{c}{ Intervensi } & \multicolumn{2}{c}{ Kontrol } \\
\cline { 2 - 5 } & Jumlah & Persen (\%) & Jumlah & Persen (\%) \\
\hline $9,01-10,00$ & 0 & 0,00 & 1 & 6,25 \\
$10,01-11,00$ & 1 & 6,25 & 2 & 12,50 \\
$11,01-12,00$ & 1 & 6,25 & 2 & 12,50 \\
$12,01-13.00$ & 1 & 6,25 & 7 & 43,75 \\
$13,01-14,00$ & 4 & 25,00 & 4 & 25,00 \\
$14,01-15,00$ & 7 & 43,75 & 0 & 0,00 \\
$15,01-16,00$ & 2 & 12,50 & 0 & 0,00 \\
\hline Total & 16 & 100,00 & 16 & 100,00 \\
\hline
\end{tabular}

Sumber: Data primer, 2020

Pada tabel 3 terlihat kadar $\mathrm{Hb}$ remaja putri yang telah diberi intervensi sari kacang hijau dan tablet tambah darah terbanyak di angka 14,01 - 15 gr\% sejumlah 7 orang $(43,75 \%)$, sedangkan kadar $\mathrm{Hb}$ remaja putri yang hanya diberikan tablet tambah darah saja terbanyak pada angka 12,01 - 13,00 gr\% juga sejumlah 7 orang (43,75 \%).

Tabel 4. Hasil Uji Bivariat Pengaruh Sari Kacang Hijau dan Tablet Tambah Darah Terhadap Kadar Haemoglobin Remaja Putri di wilayah Kerja Puskesmas Kinovaro

\begin{tabular}{ccccc}
\hline & $\mathrm{n}$ & Rerata \pm s.b & IK 95\% & $p$ \\
\hline $\begin{array}{c}\text { Kadar Hb sebelum } \\
\text { dilakukan dilakukan } \\
\text { intervensi }\end{array}$ & 32 & $12,65 \pm 1,477$ & & \\
$\begin{array}{c}\text { Kadar Hb sesudah } \\
\text { dilakukan dilakukan } \\
\text { intervensi }\end{array}$ & 32 & $13,156 \pm 1,42$ & $0,08-0,99$ & 0,022 \\
& & & & \\
\hline
\end{tabular}

Sumber: Data primer, 2020

Berdasarkan Tabel 4 , hasil uji statistik memperlihatkan nilai $p=0,022$ yang berarti terdapat perbedaan yang bermakna sebelum dan sesudah pemberian sari kacang 
hijau dan tablet tambah darah terhadap peningkatan kadar hemoglobin remaja putri di wilayah kerja Puskesmas Kinovaro.

\section{PEMBAHASAN}

Salah satu faktor yang mempengaruhi kejadian anemia adalah usia karenan pada usia remaja terjadi percepatan pertumbuhan (growth spurt) yang membutuhkan banyak asupan zat besi. Kebutuhan zat besi remaja putri lebih banyak lagi dibandingkan remaja putra, karena remaja putri mengalami menstruasi setiap bulan yang mengakibatkan kehilangan zat besi $0,8 \mathrm{mg} /$ hari selama menstruasi (Putri \& Nasution, 2019). Kadar hemoglobin sebelum dan sesudah pemberian perlakuan menunjukan bahwa umur 12 sampai dengan 16 tahun remaja masih mengalami kadar hemoglobin kurang dari batas normal yaitu $12 \mathrm{gr} / \mathrm{dL}$, hal ini dapat terjadi karena seorang remaja mengalami menstrusi, aktifitas, pola tidur yang tidak teratur seperti tidur sampai larut malam (begadang), dan sebagian remaja yang tidak suka mengkonsumsi sayur-sayuran. Hal ini sejalan dengan (Umi Farida, 2017) yang menyatakan dalam penelitiannya bahwa lebih dari separuh sampel (90\%) menderita anemia berada pada kisaran usia 13-15 tahun atau kurang dari 15 tahun. Menurut hasil penelitian dari Yuviska \& Armiyanti, (2019) berkurangnya kadar hemoglobin atau terjadinya anemia pada remaja dapat dipengaruhi oleh usia remaja putri yang sangat memperhatikan bentuk badan, sehingga sebagian remaja putri membatasi konsumsi makanan yang mengandung zat besi dan protein (Yuviska \& Armiyanti, 2019).

Hemoglobin adalah suatu senyawa kompleks yang terdiri dari protein dan zat besi ( $\mathrm{Fe}$ ) yang merupakan komponen utama dan menyebabkan warna merah pada eritrosit (Yayuningsih, Prayitno, \& Mazidah, 2018). Penelitian yang dilakukan Retno, dkk sejalan dengan hasil penelitian ini yaitu terbukti bahwa setelah mengkonsumsi tablet tambah darah dan kacang hijau kadar hemoglobin ibu hamil dapat meningkat dibandingkan dengan ibu hamil yang hanya mengkonsumsi tablet tambah darah. Pada kelompok intervensi yang diberi perlakuan berupa pemberian sari kacang hijau dan tablet tambah darah terdapat peningkatan kadar hemoglobin dari 16 orang responden yang diberi perlakuan 8 diantaranya tejadi peningkatan kadar hemoglobin yang ratarata kadar hemoglobin sebelum pemberian perlakuan yaitu 12,750 setelah dilakukan perlakuan menjadi 13, 206 dengan kenaikan kadar $\mathrm{Hb}$ 0,8 - 1.8 gr/dL sedangkan pada kelompok kontrol yang hanya diberikan tablet tambah darah Hasil dari pemeriksaan kadar hemoglobin pada 16 responden kelompok kontrol 7 diantaranya mengalami peningkatan kadar hemoglobin dengan nilai rata-rata kadar hemoglobin sebelum pemberian tablet tambah darah 12,306 sedangkan nilai rata-rata kadar hemoglobin sesudah diberi tablet tambah darah menjadi 12,219 dengan kenaikan kadar $\mathrm{Hb} 0,1$ $0.8 \mathrm{gr} / \mathrm{dL}$ (Retnorini et al., 2017). Peneliti memilih sari kacang hijau untuk meningkatkan kadar hemoglobin karena kacang hijau merupakan salah satu jenis kacang-kacangan yang mengandung zat besi tinggi. Biji kacang hijau terdiri atas tiga bagian utama, yaitu kulit biji (10\%), kotiledon (88\%) dan sisanya adalah lembaga (2\%). Kotiledon banyak mengandung pati dan serat, sedangkan lembaga mengandung protein dan lemak. Kandungan protein kacang hijau sebesar 22\% menempati urutan ketiga setelah kedelai dan kacang tanah. Kacang hijau seperti halnya kacangkacangan yang lainnya, kacang hijau dikenal sebagai sumber protein nabati karena kandungan protein cukup tinggi, yaitu sekitar 19.04-25,37\% (Aswatan, 2009).

Pemberian tablet tambah darah untuk kelompok intervensi dan kelompok kontrol yang hanya tablet tambah darah saja selama 1 minggu sekali berdasarkan Buku Panduan Untuk Siswa Aksi Bergizi, Hidup Sehat Sejak Sekarang Untuk Remaja 
Kekinian (Kementerian Kesehatan R.I., 2018c). Peneliti memberi tablet tambah darah bersama dengan pemegang program posyandu remaja di puskesmas Kinovaro, pemberian suplementasi TTD pada rematri (remaja putri) dan WUS merupakan salah satu upaya pemerintah Indonesia untuk memenuhi asupan zat besi.

Berdasarkan hasil analisis data diatas peningkatan kadar hemoglobin mengalami peningkatan karena kacang hijau merupakan salah satu tanaman pangan sumber protein nabati, kandungan protein kacang hijau sebesar $22 \%$ menempati urutan ketiga setelah kedelai dan kacang tanah. Hal ini sejalan dengan penelitian yang dilakukan bahwa pada kelompok ibu hamil yang mengkonsumsi sari kacang hijau masih rutin mengkonsumsi tablet tambah darah mampu meningkatkan kadar hemoglobin lebih baik (Jannah \& Puspaningtyas, 2018). Hasil penelitian tentang effect of consuming green bean juice on maternal blood profile during pregnancy (efek mengkonsumsi jus kacang hijau terhadap profil darah ibu selama kehamilan) ada pengaruhyang signifikan jus kacang hijau dalam meningkatkan kadar hemoglobin, hematokrit, dan eritrosit, tetapi tidak pada tingkat trombosit, pada ibu hamil yang mendapat tablet Fe (Anastasia S, Soehartono, Ngadiyono, Muchlis, \& Dyah, 2017)

Hasil penelitian lain menjelaskan bahwa terdapat 1 responden yang tidak mengalami peningkatan kadar Hemoglobin karena terlalu sering tidur malam (Santoso, Mulyati, \& Rukmana, 2020). Hal ini sejalan dengan hasil penelitian peneliti dimana terdapat 6 responden yang tidak mengalami peningkatan kadar Hemoglobin, hasil wawancara yang dilakukan hal ini terjadi dikarenakan sering tidur larut malam dan tidak suka makan sayur-sayuran. Hal tersebut menyebabkan proses regenerasi sel temasuk didalamya sel darah merah menjadi terganggu, sehingga terjadi penurunan kadar Hemoglobin.

Dalam pedoman pencegahan dan penanggulangan Anemia pada remaja putri dan wanita usia subur Kementrian Kesehatan rekomendasi global menganjurkan untuk daerah dengan prevalensi anemia $\geq 40 \%$, pemberian TTD pada remaja putri dan wanita usia subur terdiri dari 30-60 mg elemental iron dan diberikan setiap hari selama 3 bulan berturut-turut dalam 1 tahun (Kementerian Kesehatan R.I., 2018c). Hal ini sejalan dengan hasil penelitian yang menyatakan bahwa pemberian tablet tambah darah selama 2 bulan terhadap remaja putri hasil pretest dan posttestnya menunjukan adanya peningkatan bermakna sesudah pemberian tablet tambah darah. Mengkonsumsi zat besi secara terus menerus tidak akan menyebabkan keracunan karena tubuh mempunyai sifat autoregulasi zat besi (Tonasih, Rahmatika, \& Irawan, 2019)

Menurut peneliti pemberian tablet tambah darah tidak mengalami peningkatan kadar hemoglobin secera signifikat pada kelompok kontrol remaja putri di wilayah kerja puskesmas Kinovaro disebabkan karena pemberian tablet tambah darah hanya seminggu dalam sekali sehingga hasilnya tidak ada pengaruh yang signifikan terhadap peningkatan kadar hemoglobin, hasilnya akan berbeda bila pemberian dilakukan selama 3 bulan sesuai dengan pedoman pencegahan dan penanggulagan anemia pada remaja putri dan wanita usia subur (Kementerian Kesehatan R.I., 2018c). Cara mencegah anemia adalah dengan memastikan kecukupan asupan zat besi harian melalui dau cara utama, yaitu 1) mengkonsumasi makanan sumber zat besi, 2) minum tablet tambah darah untuk remaja putri. Makanan sumber zat besi misalnya hati ayam, kerang, telur, daging sapi, kacang kedelai, kacang hijau, bayam merah, dan lainnya. Untuk meningkatkan sumber nabati, dianjurkan untuk megkonsumsi buah-buahan yang mengandung vitamin C, seperti jeruk dan jambu (Rachmi et al., 2019). 


\section{SIMPULAN DAN SARAN}

Terdapat peningkatan secara signifikan kadar hemoglobin pada remaja putri setelah diberikan pemberian kacang hijau dan tablet tambah darah pada kelompok intervensi. Pada kelompok kontrol pemberian tablet penambah darah secara signifikan tidak berpengaruh terhadap peningkatan kadar hemoglobin pada remaja putri. Dimana peningkatan kadar hemoglobin kelompok intervensi lebih tinggi dari kadar hemoglobin kelompok intervensi. Dapat memberikan penyuluhan tentang manfaat sari kacang hijau untuk meningkatkan kadar hemoglobin darah, serta manfaat dari mengkonsumsi tablet tambah darah 1 minggu sekali bagi remaja putri dan bagi penelitian lain dan diharapakn dapat mengembangkan penelitian ini dengan memperpanjang waktu penelitian bagi kelompok kontrol yaitu kelompok dengan pemberian tablet tambah darah saja untuk mengetahui peningkatan kadar hemoglobin remaja putri terhadap pemberian tablet tambah darah 1 kali dalam seminggu sesuai Surat Edaran Direktorat Jendral Kesehatan Masyarakat dengan nomor HK.03.03/V/05095/2016 tentang pemberian tablet tambah darah.

\section{UCAPAN TERIMA KASIH}

Tim penulis mengucapkan terima kasih kepada Direktur Poltekkes Kemenkes Palu, Kepala Puskesmas Kinovaro, dan para remaja putri sehingga proses penelitian ini dapat terlaksanan dengan baik.

\section{DAFTAR PUSTAKA}

Anastasia S, S., Soehartono, S., Ngadiyono, N., Muchlis, M., \& Dyah, D. (2017). Effect of Consuming Green Bean Juice (Phaseolus Radiatus) on Maternal Blood Profile During Pregnancy. Belitung Nursing Journal, 3(5), 515-524. https://doi.org/10.33546/bnj.197

Aswatan, M. (2009). Sehat dengan hidangan Kacang dan biji-bijian (1st ed.). Bogor: Penebar Swadaya Grup. Retrieved from https://opac.perpusnas.go.id/DetailOpac.aspx?id=705939

Jannah, M., \& Puspaningtyas, M. (2018). Peningkatan Kadar Hb lbu Hamil Dengan Jus Kurma Dan Sari KAcang Hijau Di Kota Pekalongan. PLACENTUM: Jurnal IImiah Kesehatan Dan Aplikasinya, 6(2), 1. https://doi.org/10.20961/placentum.v6i2.22518

Kementerian Kesehatan R.I. (2018a). Laporan Nasional Riskesdas 2018. Jakarta: $\begin{array}{llll}\text { Kementerian Kesehatan } & \text { R.I. } & \text { Retrieved from }\end{array}$

http://labdata.litbang.kemkes.go.id/ccount/click.php?id=19

Kementerian Kesehatan R.I. (2018b). Laporan Riskesdas 2018 Provinsi Sulawesi Tengah. Jakarta: Badan Penelitian dan Pengembangan Kesehatan, Kementerian Kesehatan R.I.

Kementerian Kesehatan R.I. (2018c). Pedoman Pencegahan dan Penanggulangan Anemia Pada Remaja Putri dan Wanita Usia Subur (WUS). Jakarta: Kementerian Kesehatan R.I. Retrieved from https://promkes.kemkes.go.id/buku-pedoman-pencegahan-danpenanggulangan-anemia-pada-remaja-putri-dan-wanita-usia-subur

Kurniyati, E. M., Aulia, Setiawati, A. C., Suprayitno, E., Indriyani, R., \& Ahmaniyah. (2021). Sari Kacang Hijau dan Madu Meningkatkan Nilai Hemoglobin Remaja Kelas XI. Jurnal IImiah Kebidanan (Scientific Journal of Midwifery), 7(1), 12-18. https://doi.org/10.33023/jikeb.v7i1.670

Putri, F., \& Nasution, R. I. (2019). Efektivitas Minuman Kacang Hijau terhadap Peningkatan Kadar Hemoglobin Remaja Putri di Panti Asuhan di Kota Pekanbaru. Jurnal Ilmu Kedokteran, 12(2), 95-100. https://doi.org/10.26891/jik.v12i2.2018.95-100

Rachmi, C. N., Wulandari, E., Kurniawan, H., Wiradnyani, L. A. A., Ridwan, R., \& Akib, T. C. (2019). Aksi Bergizi, Hidup sehat Sejak sekarang Untuk Remaja Kekinian. Jakarta: Kementerian Kesehatan Republik Indonesia. Retrieved from https://www.unicef.org/indonesia/media/2761/file/Aksi-Bergizi-Fasilitator-2019.pdf

Retnorini, D. L., Widatiningsih, S., \& Masini, M. (2017). Pengaruh Pemberian Tablet Fe Dan 
Sari Kacang Hijau Terhadap Kadar Hemoglobin Pada Ibu Hamil. Jurnal Kebidanan, 6(12), 8. https://doi.org/10.31983/jkb.v6i12.1908

Rimawati, E., Kusumawati, E., Gamelia, E., Sumarah, S., \& Nugraheni, S. A. (2018). Intervensi Suplemen Makanan Untuk Meningkatkan Kadar Hemoglobin Pada Ibu Hamil. Jurnal IImu Kesehatan Masyarakat, 9(3), 161-170. https://doi.org/10.26553/jikm.v9i3.307

Santoso, M. B., Mulyati, R., \& Rukmana, A. F. (2020). Pengaruh sari kacang hijau ( vigna radiata) terhadap kadar hemoglobin anak usia sekolah dengan anemia defisiensi zat besi. Maternity Care and Reproductive Health, 3(2), 108-117. Retrieved from http://mcrhjournal.or.id/index.php/jmcrh/article/view/134

Tonasih, T., Rahmatika, S. D., \& Irawan, A. (2019). Efektifitas Pemberian Tablet Tambah Darah Pada Remaja Terhadap Peningkatan Hemoglobin (Hb) Di STIKes Muhammadiyah Cirebon. Jurnal SMART Kebidanan, 6(2), 106. https://doi.org/10.34310/sjkb.v6i2.292

Umi Farida, V. I. (2017). Pemberian Kacang Hijau Sebagai Upaya Peningkatan Kadar Hemoglobin Pada Remaja Putri. The 5th Urecol Proceeding, (February), 215-222. Retrieved from http://lpp.uad.ac.id/wp-content/uploads/2017/05/28.-umi-faridah215222.pdf

Yayuningsih, D., Prayitno, H., \& Mazidah, R. (2018). Hematologi: Program Keahlian Teknologi Laboratorium Medik (1st ed.). Jakarta: EGC.

Yuviska, I. A., \& Armiyanti, L. (2019). Perbedaan Pemberian Jus Kacang Hijau dan Jus Jambu Biji Merah Terhadap Peningkatan Kadar Haemoglobin. Jurnal Kebidanan, 5(1), 52-60. Retrieved from http://ejurnalmalahayati.ac.id/index.php/kebidanan/article/view/914 